\title{
Arqueologia das práticas editoriais: 15 anos de um impresso em Movimento
}

\author{
Omar Schneider ${ }^{*}$ \\ Amarílio Ferreira Neto** \\ Ana Claudia Silverio Nascimento ${ }^{* * *}$ \\ Wagner dos Santos ${ }^{* * * *}$
}

\begin{abstract}
Resumo: Neste artigo, estuda-se a arqueologia das práticas editoriais da revista Movimento em sua relação com os processos de editoração, difusão, circulação e adequação às agências indexadoras. Revela as fases do impresso, enfatizadas as escolhas dos editores com referência ao projeto gráfico do periódico que coloca em circulação diferentes aparelhos de regulação das apropriações, ao mesmo tempo em que procura criar uma identidade que qualifique o periódico como dispositivo autorizado, capaz de revelar aos leitores o que é a Educação Física no Brasil.
\end{abstract}

Palavras-chave: Revista Movimento. Avaliação. Publicações científicas e técnicas.

\section{INTRODUÇão}

Quem conhece o solo e o subsolo [...] sabe muito bem que um trecho de muro, um banco, um tapete, um guarda-chuva são ricos de idéias ou de sentimentos, quando nós também o somos, e que as reflexões de parceria entre os homens e as coisas

\footnotetext{
* Doutor em Educação: História, Política e Sociedade, pela Pontifícia Universidade Católica de São Paulo. Professor do Centro de Educação Física e Desportos da Universidade Federal do Espírito Santo; coordenador e pesquisador do Proteoria. Vitória, ES, Brasil. E-mail: omar@proteoria.org

** Doutor em Educação pela Universidade Metodista de Piracicaba. Professor do Centro de Educação Física e Desportos da Universidade Federal do Espírito Santo. Membro pesquisador do Proteoria. Vitória, ES, Brasil. E-mail: amarilio@proteoria.org

*** Doutoranda em Ciência da Informação pela Escola de Comunicações e Artes da Universidade de São Paulo. Membro pesquisador do Proteoria.Vitória, ES, Brasil. E-mail: anaclaudia@proteoria.org

**** Doutorando em Educação pela Universidade Federal do Espírito Santo. Membro pesquisador do Proteoria. Vitória, ES, Brasil. E-mail: wagner@proteoria.org
} 


\section{Astigor Especiais Omar Schneider et al.}

compõem um dos mais interessantes fenômenos da terra. A expressão: 'Conversar com os seus botões', parecendo simples metáfora, é frase de sentido real e direto (ASSIS, 1973, p. 103).

Alicerçado nas propostas de estudo dos impressos, principalmente na pesquisa "A constituição de teorias da Educação Física: o debate em periódicos no século XX”, o Instituto de Pesquisa em Educação e Educação Física (PROTEORIA), ${ }^{1}$ desde o ano 2000, busca criar condições para compreender, por meio da imprensa educacional (ensino, técnico e científica), a forma como, no Brasil, foi e vem sendo produzida uma teoria para a Educação Física. Como, em determinados momentos, agentes sociais dotados de competências específicas se apropriam, sistematizam e fazem uso do conjunto de saberes provenientes de diferentes áreas do conhecimento, para significar o papel da Educação Física na sociedade, e, mais especificamente, no interior das instituições educacionais como disciplina escolar.

A abordagem que o Proteoria elegeu para o estudo do mundo dos impressos faz a opção de analisar o periódico como objeto de estudo, o que demanda deslocar o modo de interrogar esse dispositivo. Esse deslocamento se opera na medida em que o impresso é perspectivado não somente como veículo dos discursos pedagógicos, das prescrições que por meio dele se põem em circulação, mas como produto das pedagogias, entendidas como sistema de regras que regulam os próprios processos de produção, difusão e apropriação desses saberes (CARVALHO, 2001).

Este estudo nasce com o propósito de caracterizar a Movimento, ${ }^{2}$ de centrar a análise na sua materialidade. Nesse sentido, o foco é direcionado para os aspectos formais do impresso, para as

\footnotetext{
${ }^{1}$ Endereço para contato: http://www.proteoria.org ou proteoria@proteoria.org.

2 Impresso da Escola de Educação Física da Universidade Federal do Rio Grande do Sul (ESEF/UFRGS). Do ano de seu nascimento, 1994, até os dias atuais, foram publicados 39 números, dos quais um é uma edição especial. Até o momento, a revista teve cinco editores, que, em diferentes situações, estiveram à frente do impresso, de forma individual: Marco Paulo Stigger (1994-1996); Jorge Luiz de Souza (1996-1999) e Vicente Molina Neto (1999-2002); ou compondo um grupo de editores: Vicente Molina Neto, Silvana Vilodre Goellner e Marco Paulo Stigger (2002-2004), Vicente Molina Neto e Marco Paulo Stigger (2005-2008) e Marco Paulo Stigger e Alex Branco Fraga (2009-).

Movimento, Porto Alegre, v. 15, n. 03, p. 57-85, julho/setembro de 2009.
} 
temáticas que são colocadas em circulação e para as "adequações" que a revista vem realizando na sua formatação para se "ajustar" aos critérios que as agências indexadoras estabelecem para a avaliação dos periódicos científicos. ${ }^{3}$

Nunes (1992, p. 152), ao propor a análise do objeto pela materialidade, faz com que se rompa a "[...] cristalização das matrizes interpretativas", o que permite que se produzam novas abordagens de velhos objetos. Nunes e Carvalho (1993, p. 44) esclarecem que "[...] esses 'velhos' objetos tornam-se [...] 'novos', porque são apanhados numa perspectiva que realça sua materialidade de dispositivos, através dos quais bens culturais são produzidos, postos a circular e apropriados”. Desse modo, a metodologia amparada pela História Cultural apresenta-se como a possibilidade de "[...] uma arqueologia dos objetos [...], (procurando) apanhá-los na sua forma, sua freqüência, seu dispositivo (e) sua estrutura" (NUNES; CARVALHO, 1993, p. 45). Projetar a investigação utilizando as técnicas da arqueologia, ${ }^{4}$ de acordo com Carvalho (1998, p. 4), “[...] implica tratar o impresso a ser analisado como objeto cultural que, constitutivamente, guarda as marcas de sua produção e de seus usos”.

Nos estudos que tomam a imprensa periódica como objeto de análise, com base nas proposições da História Cultural, o conceito de estratégia é fundamental, pois permite que se evidenciem "[...] os dispositivos de imposição de saberes e normatização de práticas"

\footnotetext{
${ }^{3} \mathrm{~A}$ busca permanente pela criação de critérios de qualidade para periódicos aparece, ao mesmo tempo, como consequência e incentivo aos pesquisadores pela divulgação de seus artigos nos mais respeitados veículos. Na medida em que o reconhecimento científico orienta a produção das revistas, os critérios de avaliação dessas publicações ditam as metas a serem alcançadas pelas equipes editoriais (GRUSZYNSKI; GOLIN; CASTEDO, 2008).

${ }^{4}$ Para Veyne (1998), toda história é arqueológica por natureza e não por escolha: explicar a história consiste em vê-la em seu conjunto, em correlacionar os pretensos objetos naturais com as práticas datadas e raras que os objetivizam, e em explicar essas práticas não apenas com relação a uma causa única, mas com base em todas as práticas vizinhas nas quais se ancoram. Ao analisar o uso da Arqueologia e seu instrumental teórico no campo da História, Schnapp (1988, p. 4) discute que "[...] a forma indica a destinação, [e que] o modo de fabricação indica uma certa organização [...]", assim, os testemunhos residuais de uma cultura correspondem à materialidade e à formalidade das práticas produzidas pela sociedade da qual é originária.

${ }^{5}$ Usando como suporte teórico os estudos de Certeau (1996, p. 46), o conceito de estratégia é empregado como "[...] o cálculo das relações de forças que se torna possível a partir do momento em que um sujeito de querer e poder é isolável de um 'ambiente'. O conceito postula um lugar

Movimento, Porto Alegre, v. 15, n. 03, p. 57-85, julho/setembro de 2009.
} 
(CARVALHO, 1998, p. 4). Essa operação tem por objetivo conhecer o aparelho crítico $^{6}$ do impresso, o que significa focar a atenção aos múltiplos dispositivos que são produzidos pelos editores a fim de aumentar seu controle sobre a leitura, ou a didatização do objeto para um uso modelar.

\section{A ARQUEOLOGIA DO IMPRESSO: A REVISTA MOVIMENTO E SUA MATERIALIDADE}

As coisas têm peso, massa, volume, tamanho tempo, forma, cor, posição, textura, duração, densidade, cheiro valor, consistência, profundidade, contorno temperatura, função, aparência, preço destino, idade, sentido [...] (ANTUNES, 1992, p. 91).

Como o lugar em que o leitor tem o primeiro contato com o impresso, as capas de um periódico são importantes para estabelecer um padrão de reconhecimento. Elas revelam ao leitor, antecipadamente, o que é a revista, sem que a tenha que folhear. Na produção da fórmula editorial do impresso, investimentos são feitos em relação a esse dispositivo para que o periódico se torne mais atraente aos leitores. $^{7}$

capaz de ser circunscrito como um próprio e portanto capaz de servir de base à gestão de suas
relações com uma exterioridade distinta". No que se refere especificamente aos estudos dos
impressos, aproxima-se das reflexões realizadas por Carvalho (1998) que, utilizando as propo-
sições de Certeau (1996), indica que a estratégia se remete "[...] a práticas cujo exercício
pressupõe um lugar de poder [...], [que] aplicado, por exemplo, a uma história dos impressos de
destinação escolar [...], põe em evidência dispositivos de imposição de saberes e normatização
de práticas" (CARVALHO, 1998, p. 4).
${ }^{6}$ O aparelho crítico é a forma como os dispositivos (elementos que compõem uma estratégia)
são hierarquizados em um suporte material com a finalidade de didatizar seu uso, em determi-
nada situação de manuseio e controle da leitura, ou sofisticação de seu design, com o objetivo
de torná-lo mais atraente ao público consumidor. O aparelho crítico, nesse sentido, é mais do
que um mediador do discurso, ele molda a forma da apropriação do discurso. "Daí, então, a
atenção dispensada, mesmo que discreta, aos dispositivos técnicos, visuais e físicos que
organizam a leitura do escrito" (CHARTIER, 1994, p. 8).
7 Para Oliveira e Schincariol (2007, p. 1-2), o projeto editorial da capa de um impresso é
elemento que deve ser analisado para se compreender a identidade de um periódico, pois "[...]
[ela] caracteriza suas edições como pertencentes a uma série e, ao mesmo tempo, sinaliza a
singularidade de cada exemplar. Assim, a articulação entre elementos constantes e variáveis
pode possibilitar ao leitor [....] [a] percepção de individualidade com presença no conjunto".

Movimento, Porto Alegre, v. 15, n. 03, p. 57-85, julho/setembro de 2009. 
Do primeiro exemplar ao número 11, publicado em 1999, a capa da revista é produzida com um layout ${ }^{8}$ em duas cores, delimitada na borda superior por uma faixa branca horizontal, de $21 \mathrm{~cm}$, por $6,5 \mathrm{~cm}$ de largura, que traz o nome ${ }^{9}$ do periódico em uma fonte que também procura representar movimento, conhecida como Staccato $222 \mathrm{BT}$, na cor preta, que ocupa quase a totalidade do espaço. Abaixo do título que dá nome ao impresso, é indicada a filiação institucional da publicação, em uma fonte serifada ${ }^{10}$ (Times New Roman) em negrito, o ano da revista, o número da publicação e o ano de lançamento. Na parte inferior da composição, é impressa uma figura, geralmente com um grafismo em tons de cinza que apresenta uma modalidade da cultura de movimento, sobre um fundo em uma única cor que varia de um número para o outro. ${ }^{11}$

A aparente invisibilidade dos recursos tipográficos adotados, no caso de uma publicação [...], pode estar indicando uma eficaz estratégia de comunicação onde o objetivo principal está ligado a uma leitura funcional (GRUSZYNSKI, 2006, p. 11).

Até a publicação do número 11 (1999), a diagramação que identificava a revista, que possuía um sentido de austeridade, de certo modo minimalista (GRUSZYNSKI, 2008) no uso dos elementos gráficos e da paleta de cores, passa por severa modificação. No número especial, a primeira capa é apresentada com os elementos gráficos reposicionados. A divisão das cores deixa de ser horizontal e passa

\footnotetext{
${ }^{8}$ Resultado final do conjunto de operações utilizadas para dispor títulos, textos, gráficos, fotos, mapas e ilustrações na página de uma publicação ou em qualquer impresso de forma equilibrada, funcional e atraente, estabelecendo um sentido de leitura que atenda à determinada hierarquia de assuntos.

${ }_{9}^{9}$ Segundo Oliveira e Schincariol (2007, p. 2), "O elemento principal de identificação constante é o nome da revista e a forma como ele é apresentado. Para os leitores, o reconhecimento se dá através da relação precisa entre o nome, o design do nome e o conteúdo da revista".

${ }^{10} \mathrm{Na}$ tipografia, as fontes são classificadas em tipos com ou sem serifas, que correspondem aos pequenos traços e prolongamentos que ocorrem no fim das hastes das letras. As fontes serifadas são usadas em blocos únicos de texto, pois tendem a guiar o olhar durante a leitura uma vez que a leitura é feita por palavras e não por letras. Assim, as fontes serifadas parecem juntar-se em função dos seus prolongamentos, unindo as palavras. Por outro lado, as fontes sem serifas são utilizadas em títulos e chamadas, pois valorizam cada palavra e tendem a ter maior peso e presença, já que parecem mais limpas.

${ }^{11}$ Somente no ano 2000 é que o formato que caracteriza a revista e dá a ela uma identidade visual passa por reformulações, a partir da publicação de um número especial.

Movimento, Porto Alegre, v. 15, n. 03, p. 57-85, julho/setembro de 2009.
} 


\section{Antigor Especiais}

Omar Schneider et al.

a ser vertical, com o nome da revista ainda impresso em um tipo Staccato 222 BT, mas agora, com o primeiro "M" em caixa-alta, na posição vertical, na fonte Arial Bold, sobre uma borda que simula a projeção em alto-relevo. ${ }^{12}$

As modificações no layout da primeira capa acompanham um processo de reorganização da diagramação interna que havia sido iniciado pelo editor Jorge Luiz de Souza na Revista n. 10 (1999). Antes não havia a preocupação em otimizar o espaço interno do periódico, ${ }^{13}$ pois eram empregados outros recursos para a composição, espacialização e articulações entre as imagens, os textos e as diferentes fontes tipográficas. As ilustrações que compõem o projeto editorial nos primeiros nove números foram utilizadas para motivar uma leitura crítica das informações que os artigos se propunham debater. O dispositivo objetivado na forma das ilustrações é um recurso muito bem projetado, pois funciona como textos significativamente repletos de mensagens formadoras. ${ }^{14}$ Nesse processo, há também o uso marcante do contraste entre o texto e o espaço vazio. ${ }^{15}$

Conforme Chartier (2002, p. 244), a “[...] disposição da paginação, os modos de recorte do texto, as convenções tipográficas são investidos de uma 'função expressiva' e sustentam a construção da significação". Produzidas por uma intenção de controle e didatização, as convenções tipográficas possuem produtores - editores e técnicos tipográficos - e destinatários, as comunidades de leitores. Nesse processo, o que se busca é a criação de uma apropriação modelar, que seja tanto informativa quanto formativa.

\footnotetext{
${ }^{12}$ A edição especial marca a adoção de um novo layout, que passa a servir de modelo até o número 14. Na publicação do número 12, o editor, Vicente Molina Neto, afirma que as modificações visavam a "[...] sobretudo, por meio da forma [...], valorizar o conteúdo de qualidade que tem caracterizado a Revista" (MOLINA NETO, 2000, p. 4).

${ }^{13}$ Do primeiro até o número 9 (1998), havia a preocupação em produzir uma composição gráfica do miolo do periódico utilizando versões ilustrativas dos textos, ou a eles complementares. Nesse sentido, as ilustrações funcionavam como meio para representar visualmente as informações impressas.

${ }^{14}$ Para Chartier (1990, p. 179), uma imagem, uma ilustração "[...] induz uma leitura fornecendo uma chave que indica através de que figura deve ser entendido o texto".

${ }^{15} \mathrm{Na}$ diagramação, os espaços vazios são projetados como meio para hierarquizar e valorizar a relação entre textos e ilustrações, dispositivo utilizado para guiar o olhar no momento da leitura e apropriação do conteúdo.

Movimento, Porto Alegre, v. 15, n. 03, p. 57-85, julho/setembro de 2009.
} 
Apesar de essa fórmula editorial adotada pelo editor para a espacialização e hierarquização das informações veiculadas, utilizada para modelizar a leitura, ser eficiente, não se deve desconsiderar uma estética da recepção (LIMA, 1979) e as operações empregadas pelos leitores, tanto de rebeldia como de vadiagem, que opera nos limites de uma dialética das estratégias ${ }^{16}$ de imposição de sentido e das práticas/táticas de apropriação ${ }^{17}$ das mensagens veiculadas.

A fórmula editorial empregada até número 9 possuía alto custo para a sua confecção. São menores espaços para publicação de artigos, ensaios, resenhas e resumos. Os espaços vazios, as ilustrações e as chamadas laterais compõem um aparelho crítico eficiente na didatização e no controle da leitura, mas demandam um maior tempo do editor na tarefa de calcular a relação entre o texto, as ilustrações e as epígrafes laterais para que funcionem como dispositivo modelizador da leitura e das apropriações permitidas. Em relação à manutenção dessa prática editorial e da preservação da periodicidade, a decisão foi reformular seu aparelho crítico. Sobre esse tema, Souza, em editorial da revista número 10 (1999), informa:

\begin{abstract}
Nesta fase de transição estão sendo realizadas algumas modificações na estrutura da revista. Aumentou-se o espaço virtual, eliminando-se às ilustrações apresentadas no início de alguns artigos e retirando-se o espaço destinado às notas laterais, denominadas 'chamadas de páginas'. Isso permitiu a publicação de um maior número de artigos em um mesmo exemplar (SOUZA, 1999, p. 2)
\end{abstract}

Na revista número 11 (1999), a diagramação do miolo traz as mudanças anunciadas no exemplar anterior, com exceção das chamadas laterais, dispositivo usado para imprimir epígrafes do texto,

\footnotetext{
${ }^{16}$ Essa dialética, para Chartier (1994), que trabalha dentro das possibilidades, dos limites de transgressão e das liberdades refreadas, não é a mesma em toda parte, sempre e para todos, pois um impresso é um objeto "[...] cujas formas comandam, se não a imposição de um sentido ao texto que carregam, ao menos os usos de que podem ser investidos e as apropriações às quais são suscetiveis" (CHARTIER, 1994, p. 8).

${ }_{17}$ Para Certeau (1994, p. 46-47), "A tática só tem por lugar o do outro [...], a tática depende do campo do outro. Joga lance a lance, na busca de auferir ganho. Pode-se dizer que a tática está em movimento permanente (capta no vôo) para auferir legitimidade no campo do outro, o que lhe garante um não-lugar estratégico".

Movimento, Porto Alegre, v. 15, n. 03, p. 57-85, julho/setembro de 2009.
} 


\section{Antigor Especiais}

Omar Schneider et al.

aparelho crítico que antecipa para o leitor algo que os editores acreditam que ajudará na compreensão do conteúdo. ${ }^{18}$

$\mathrm{Na}$ tarefa de reorganização do projeto, outros dispositivos são empregados, entre eles, a antecipação para o leitor do conteúdo que será discutido. Vê-se, assim, o sumário também apresentado na primeira capa, na qual são impressos os temas que circularam naquele número, entre eles, ao qual é concedido maior destaque e que os editores consideram polêmico na Educação Física brasileira. O sumário somente é utilizado nos números 12 e 13, mas o dispositivo editorial de antecipar aos leitores os temas polêmicos continua a ser impresso até o número 16, quando um novo projeto gráfico é introduzido na feitura da revista.

As modificações apresentadas no número especial são resultados de um acordo iniciado entre o editor da Movimento, naquele período, o Jorge Luiz de Souza, e o da Revista Perfil, ${ }^{19}$ Vicente Molina Neto. Conforme o editor da Movimento, após algumas reuniões com a comissão editorial dos dois periódicos, propôs-se a sua unificação, também, que o impresso passaria a ser trimestral ${ }^{20}$ e a ser chancelado pelo curso de estudos de pós-graduados em Ciências do Movimento Humano da ESEF/UFRGS.

No entanto, a unificação não foi concretizada e, no segundo volume de 1999, circula a seguinte observação:

Quanto à fusão das duas Revistas, Movimento e Perfil, não obtivemos o consenso necessário. A dúvida permanece. No entanto, entendemos que o processo deve ser progressivo. Assim, independente

\footnotetext{
${ }^{18}$ São extratos retirados do original que os editores julgaram ser suficientemente interessantes para fixar uma leitura modelar, o sentido correto proposto para o uso e para a apropriação autorizada.

${ }^{19}$ Publicação do Mestrado da ESEF/UFRGS, com periodicidade anual e editada com a finalidade de circular a produção (artigos oriundos de trabalhos e dissertações) dos docentes e discentes do Programa em Ciências do Movimento Humano. Nas palavras da comissão editorial (1997, p. 2): "A Revista Perfil será o espaço doméstico de estímulo ao exercício permanente do relato escrito das produções de alunos e professores do nosso mestrado". Ela começa a ser publicada em 1997 e deixa de ser editada em 2000, com o professor Vicente Molina Neto, coordenador do Mestrado, como editor responsável pelo impresso. Foram publicados apenas quatro números, com uma tiragem de 300 exemplares por edição.

Movimento, Porto Alegre, v. 15, n. 03, p. 57-85, julho/setembro de 2009.
} 
do que venhamos a fazer no futuro, uma providência urgente foi tomada: estamos procedendo a unificação dos seus conselhos editoriais (MOLINA NETO, 1999, p. 2).

No ano 2000, a Revista Perfil continua a ser impressa e, na Movimento, no número 15 (2001), o editor divulga a intenção da publicação de um quinto exemplar e das providências que estavam sendo tomadas para o ajustamento do impresso às demandas da comunidade científica. Apesar do anúncio, não ocorreu a publicação de um quinto número da Revista Perfil. ${ }^{21}$ Em função de uma avaliação negativa que a Movimento recebe da comissão de avaliação da Coordenação de Aperfeiçoamento de Pessoal de Nível Superior (CAPES), as energias deveriam ser direcionadas para um periódico que conseguisse cumprir os critérios para a avaliação. As medidas tomadas foram: o aumento da periodicidade, que passa de semestral para quadrimestral, e a produção de um novo layout.

Com as mudanças, no ano de 2002, faz-se o anúncio de que a editoria da Movimento seria realizada pelos professores Vicente Molina Neto, Silvana Vilodre Goellner e Marco Paulo Stigger. As modificações são materializadas no terceiro exemplar, quando é tomada a decisão de ressignificar a identidade que o impresso havia assumido de ser um "guarda-chuva". As alterações são apresentadas como uma forma de a revista tornar-se especializada, naquilo que, segundo os editores, seria doravante a inspiração do projeto editorial, as ciências humanas e sociais.

No ano de 2003, os editores fazem a terceira modificação no layout, que permanece até a atualidade. A revista passa a ser impressa no

\footnotetext{
${ }^{20}$ Apesar do anúncio da trimestralidade para o ano de 1999, possivelmente essa meta somente será atingida em 2009.

21 Já na publicação do número 11 (1992) da Movimento, Vicente Molina Neto, editor da Revista Perfil, assume a edição dos dois periódicos, possivelmente em função de, naquele momento, ele ser o coordenador do curso de Pós-Graduação Stricto Sensu em Ciências do Movimento Humano da ESEF/UFRGS. No ano de 2002, quando o editor, Vicente Molina Neto, anuncia que essa função passaria a ser coletiva, faz-se a seguinte declaração: "[...] a função de editor da Revista Movimento, responsabilidade que me foi delegada pelo grupo político que [...] [dirigia] a ESEF da UFRGS [...] [naquele] período, [foi delegada] muito mais em consideração às relações interpessoais que mantivemos até então, do que, propriamente, à propensão e ao talento para a função" (MOLINA NETO, 2002, p. 6).

Movimento, Porto Alegre, v. 15, n. 03, p. 57-85, julho/setembro de 2009.
} 


\section{Antigor Especiais}

Omar Schneider et al.

formato livro, nas dimensões $15 \times 21 \mathrm{~cm}$, apenas com uma coluna, diferentemente de todos os exemplares anteriores, diagramados em duas colunas. Suprime-se o dispositivo editorial das epígrafes introduzidas nos textos, diminuído os espaços vazios dentro do impresso.

A Figura 1 representa o ritmo de publicação da revista e sua periodicidade durante os 15 anos em que está sendo editada.

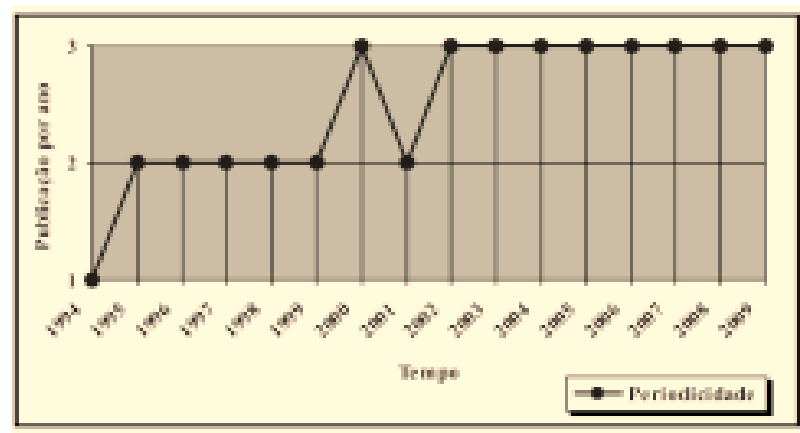

Figura 1 - Ritmo de produção da revista Movimento (1994-2009)

Com o que foi analisado, é possível projetar o ritmo da Movimento, com base em seu layout, ${ }^{22}$ em três fases distintas. Um primeiro momento de um design funcionalista ${ }^{23}$ que privilegia uma primeira capa limpa e uma diagramação interna preocupada com o uso positivo dos espaços vazios e atenta ao cálculo da distribuição do aparelho crítico na composição do impresso. Esta fase foi coordenada por dois editores: Marco Paulo Stigger (1994-1996) e depois por Jorge Luiz de Souza (1996-1999).

Uma segunda fase é o que se pode chamar de design de transição, em que há a proposta, por parte do editor, de adesão aos critérios que possibilitem a indexação às bases de dados nacionais e

\footnotetext{
${ }^{22}$ Para o entendimento das formas de avaliação do projeto gráfico dos periódicos científicos, ver Castedo e Gruszynski (2005)

${ }^{23}$ Para a área do Desenho Industrial (Programação Visual), um design funcionalista constitui-se na economia, no uso das fontes, articulação de um repertório de elementos gráficos que, repetindose, assegurem a identidade do projeto, uso positivo do espaço em branco e contrastes e espaços sem "interesse" para a obtenção do equilíbrio visual (GRUSZINSKI, 2008).
}

Movimento, Porto Alegre, v. 15, n. 03, p. 57-85, julho/setembro de 2009. 
internacionais. Esse momento é marcado pela gestão editorial de Vicente Molina Neto (1999-2002), que propõe novos layouts. É um período de teste de um novo padrão de diagramação, tanto da primeira capa quanto do miolo. São introduzidos dispositivos editoriais para adequação aos critérios de feitura de periódicos científicos e para o controle da leitura.

A terceira fase configura-se como design livro, em que a revista assume um padrão testado por outros periódicos científicos. Sua configuração é marcada por um novo layout, externo e interno, o que produz uma outra forma de reconhecimento. É também um momento de reorganização da comissão editorial, que passa a ser composta por pesquisadores que se vinculam às ciências humanas $\mathrm{e}$ sociais. Desse modo, a nova política editorial representa a busca da consolidação das linhas de pesquisa, desenvolvida por alguns professores na graduação e na pós-graduação da ESEF. ${ }^{24}$

\section{DISTRIBUIÇÃO DO CONTEÚDO: O SENTIDO EM MOVIMENTO}

O projeto da Movimento, como exposto no seu primeiro editorial, permitia a publicação de textos oriundos de variadas matrizes teóricas, uma vez que o projeto editorial pretendia "[...] abranger a pluralidade dos interesses [...] contemplando diversas abordagens acerca do movimento humano" (STIGGER, 1994, p. 4). Apesar desse interesse, é possível observar que houve a construção de uma seção, denominada Temas Polêmicos, ${ }^{25}$ que refletia a identidade discursiva

\footnotetext{
${ }^{24}$ Respeita-se a posição da ESEF/UFRGS, todavia há "Intensa proliferação de revistas técnico-cientificas, com títulos que surgem, interrompem, morrem e ressurgem, num ciclo quase anárquico. Às vezes, pretendem atender aos anseios de grupos isolados, publicando, sobretudo, artigos dos próprios membros do conselho editorial, às vezes resultam de disputas departamentais, quando buscam-se estabelecer distinção de qualidade via publicação 'científica'. Às vezes, surgem para acolher recomendações das agências financiadoras referentes à produção cientifica: o temor de não conseguir aprovação nas 'grandes' revistas faz com que coordenações de pósgraduação criem seus próprios veículos" (BARRADAS; TARGINO, 2008, p. 17-18). Recomendase ainda a leitura de Biojone (2003) e Waters (2006).

${ }^{25}$ A seção Temas Polêmicos foi veiculada em 13 dos 18 números publicados, até o ano de 2002. Embora, em alguns números, ela não esteja presente, foi objeto de destaque nos editoriais, tanto pela presença como pela sua ausência. Na educação, essa prática editorial ocorreu na década de 1980. Por exemplo, na seção debates da revista Educação \& Sociedade, com os artigos de Nosella (1983) e Saviane (1983).

Movimento, Porto Alegre, v. 15, n. 03, p. 57-85, julho/setembro de 2009.
} 
do impresso e sua diferenciação no conjunto de periódicos científicos da área. Para Stigger (1995), as ideias que circulassem na seção constituiriam a maior contribuição para a área, já que nela estaria mobilizado o esforço de um bom número de pensadores da Educação Física.

As temáticas privilegiadas na Movimento, como pode-se perceber no Quadro 1, garantem homogeneidade à proposta e podem revelar elementos para se compreender o seu projeto editorial.

\begin{tabular}{|l|l|l|}
\hline \multicolumn{1}{|c|}{ Temas Polêmicos } & \multicolumn{1}{|c|}{ Autores } & \multicolumn{1}{c|}{ Número/Ano } \\
\hline \multirow{4}{*}{ O que é Educação Física } & Gaya (1994); Taffarel e Escobar (1994) & Ano I, n. 1 \\
\cline { 2 - 3 } & $\begin{array}{l}\text { Bracht (1995); Santin (1995); Ghiraldelli } \\
\text { Jr. (1995); Lovisolo (1995) }\end{array}$ & Ano II, n. 2 \\
\cline { 2 - 3 } & Costa (1996); Palafox (1996) & Ano III, n. 4 \\
\hline \multirow{4}{*}{$\begin{array}{l}\text { Educação Física Escolar } \\
\text { Aptidão Física-Saúde }\end{array}$} & Gaya et al. (1997) & Ano III, n. 6 \\
\cline { 2 - 3 } & Lovisolo (1997) & Ano IV, n. 7 \\
\cline { 2 - 3 } & Gaya, Torres e Cardoso (1998) & Ano IV, n. 8 \\
\cline { 2 - 3 } $\begin{array}{l}\text { Verticalidade é sinônimo } \\
\text { de boa postura? }\end{array}$ & Gaya, Torres e Cardoso (1998) & Ano V, n. 9 \\
\hline \multirow{4}{*}{$\begin{array}{l}\text { Esporte na Escola e Esporte } \\
\text { de Rendimento }\end{array}$} & Kunz (2000); Bracht (2000) & Ano V, n. 10 \\
\cline { 2 - 3 } & Gaya (2000); Taffarel (2000) & Ano VII, n. 12 \\
\cline { 2 - 3 } & Stigger (2001); Vaz (2001) & Ano VII, n. 14 \\
\cline { 2 - 3 } & Lovisolo (2001) & Ano VII, n. 15 \\
\hline A formação profissional & Molina Neto e Molina (2002) & V. 8, n. 1 \\
\hline
\end{tabular}

Quadro 1. Circulação dos temas polêmicos, autores, número e ano do impresso

A discussão iniciada na seção Temas Polêmicos, no primeiro número, por Gaya (1994), Taffarel e Escobar (1994), sobre "O que é Educação Física?", continuou com diversos autores, como pode ser observado no Quadro 1. Pode-se perceber que, entre os diferentes autores convidados para participar do debate, uma preocupação em particular ganha destaque, qual seja, a definição dos contornos sobre o estatuto epistemológico da área. ${ }^{26}$

\footnotetext{
${ }^{26}$ Essa é uma discussão que não se restringe à revista. Na realidade, representa um movimento que ganha força, sobretudo, na década de 1990, e que se fez ecoar em simpósios, congressos periódicos, livros, dentre outros espaços de produção/divulgação de conhecimento.

Movimento, Porto Alegre, v. 15, n. 03, p. 57-85, julho/setembro de 2009.
} 
Dos temas problematizados na seção em destaque, os que ganharam maior atenção da comunidade científica foram "O que é Educação Física" e o "Esporte na Escola e Esporte de Rendimento". De maneira induzida, diferentes atores e autores debateram sobre a importância do esporte como elemento significativo e fundante da cultura corporal de movimento e de seu papel nos processos de formação do sujeito. Entre aproximações e distanciamentos, os autores oferecem reflexões sobre o sentido atribuído ao esporte no interior da escola e os diferentes fundamentos epistemológicos utilizados para identificá-lo e compreendê-lo. ${ }^{27}$

A decisão de colocar em pauta a "Formação Profissional" foi impulsionada pelos novos dispositivos legais aprovados pelo Conselho Nacional de Educação, sobretudo aquele que se refere ao Parecer n. ${ }^{\circ}$ 009/2001, que estabelece Diretrizes Curriculares Para a Formação de Professores da Educação Básica, em nível superior, Curso de Licenciatura, e o Parecer 021/2001 que dispõe sobre a duração e carga horária dos cursos de Formação de Professores. Apesar de a revista ter investido em um tema que se apresentava extremamente atual, em função da sua relevância política e acadêmica, não houve demanda de produção sobre o assunto. ${ }^{28}$

Além da dificuldade em manter uma regularidade na publicação da seção, os editores elaboram, no ano de 2003, várias adequações ao projeto editorial da Movimento. Nesse caso, as estratégias propostas pelos editores para adequar os padrões técnicos da revista às exigências dos indexadores nacionais e internacionais tiveram implicações não só nas reformulações de seus procedimentos administrativos, de seu conselho editorial e do seu projeto gráfico, conforme

${ }^{27}$ Os desdobramentos do debate provocado pela Movimento, no que tange à temática "Esporte na Escola e Esporte de Rendimento", foram recentemente reapresentados com a publicação do livro "Esporte de Rendimento e Esporte na Escola", organizado por Stigger e Lovisolo (2009). Esse livro retoma os artigos publicados na seção Temas Polêmicos.

${ }^{28}$ Apesar de não ter havido resposta, no âmbito da revista, ao tema, ele foi debatido em outros espaços. Por exemplo, na Revista Brasileira de Ciência do Esporte, por Andrade Filho (2001) e no segundo volume da coleção Educação Física: política, investigação e intervenção, por Andrade Filho e Figueiredo (2004). Uma vez que a seção Temas Polêmicos é aberta por indução do editor, ou por demanda espontânea dos colaboradores, ela somente pode funcionar quando há a mobilização da comunidade para fazer o debate acontecer ou quando os temas são realmente polêmicos.

Movimento, Porto Alegre, v. 15, n. 03, p. 57-85, julho/setembro de 2009. 
foi destacado no editorial número 3 de 2002, mas no próprio conteúdo veiculado no impresso. Para os editores, seria necessário " [...] abandonar o caráter 'guarda-chuva', especializar-se e buscar, doravante, desenvolver seu projeto editorial sob a inspiração das ciências humanas e sociais" (MOLINA NETO; GOELLNER; STIGGER, 2002, p. 4).

Na capa do volume 8 , número 1 , é possível perceber que existe uma outra transição acontecendo. Nela há a indicação da seção Em Foco, todavia, no sumário, ainda permanece a referência à seção Temas Polêmicos. Essa substituição, de fato, vai acontecer no volume 9, número 1, em 2003. De acordo com os editores, na seção Em Foco, ficariam reunidos os trabalhos que correspondessem a uma temática definida pela Comissão Editorial, como central da edição. Essa seção se fez presente em 12 números, ou seja, do v. 9, n. 1 (2003) ao v. 12, n. 3 (2006). ${ }^{29}$

Diante das dificuldades em conseguir artigos suficientes para constituir uma temática que fosse o foco central de uma edição, a proposta deixa de ser viável e a revista retorna ao formato não temático ou, como enfatizaram os editores, “[...] na forma de demanda livre e contínua" (MOLINA NETO; STIGGER, 2006, p. 8). De acordo com os editores, a cada número editado e a cada artigo publicado, o periódico evidenciava uma determinada "[...] perspectiva de ver as coisas da Educação Física, provocando a reflexão, o aprimoramento e a renovação de propostas e discursos sobre o que é esta área interdisciplinar" (MOLINA NETO; STIGGER, 2008, p. 8).

É possível salientar que, mesmo que a tematização não tenha sido um dispositivo editorial constante na fórmula da revista, uma leitura dos conteúdos por ela abordados, permite estabelecer algumas aproximações, como pode ser observado no Quadro 2. Ao analisar o título, o resumo e os descritores dos trabalhados publicados nos 39

\footnotetext{
${ }^{29}$ Os temas publicados foram: esporte; educação física, esporte e lazer; pedagogias do corpo e da saúde; formação; lazer; história da educação física; práticas pedagógicas escolares e não escolares; linguagens, comunicação e arte; políticas públicas no âmbito do esporte, do lazer e da educação física; gênero; pesquisa qualitativa, as ciências humanas, a educação física e o esporte; corpo, cultura e saúde. É possível identificar várias perspectivas teóricas sustentando os textos que são veiculados na seção. O que é comum entre eles é a compreensão dos objetos de análise com base nas ciências humanas e sociais.

Movimento, Porto Alegre, v. 15, n. 03, p. 57-85, julho/setembro de 2009.
} 
números da Movimento, agrupou-se o conteúdo do impresso em 11 convergências temáticas.

\begin{tabular}{|c|c|}
\hline Temáticas e Número de Artigos Publicados & $\begin{array}{l}\text { Convergência } \\
\text { Temática }\end{array}$ \\
\hline $\begin{array}{l}\text { Conteúdos de ensino (6); Trabalho docente (9); Avaliação } \\
\text { educacional (1); Concepção de jogo (2); Educação Física } \\
\text { na Educação Básica (4); Abordagens Teórico-Metodológicas } \\
\text { (16); Currículo (4); Representação social do professor } \\
\text { de Educação Física (7); Educação Física e Mídia (2) }\end{array}$ & Educação Física Escolar \\
\hline $\begin{array}{l}\text { Currículo e formação profissional (8); Formação continuada (2); } \\
\text { Formação docente (9) }\end{array}$ & Formação de professor \\
\hline $\begin{array}{l}\text { Efeitos da aprendizagem no esporte (1); Estudo da aprendizagem } \\
\text { motora (9); Percepção de professores em relação } \\
\text { à aprendizagem motora (1) }\end{array}$ & Aprendizagem motora \\
\hline $\begin{array}{l}\text { Significado do corpo na cultura (11); Corpo e a Revista Boa } \\
\text { Forma (1); Corpos masculinos e femininos em academias } \\
\text { de Ginástica (1) }\end{array}$ & Corpo \\
\hline $\begin{array}{l}\text { Estudos em periódicos da Educação Física brasileira (5); História } \\
\text { do Movimento estudantil (1); Fontes históricas (1); O futebol } \\
\text { como objeto de estudo (5); A escolarização da Educação Física } \\
\text { e a gymnastica (1); Educação dos corpos brasileiros no início } \\
\text { do século XX (2); A Educação Física no Colégio Estadual } \\
\text { do Espírito Santo (1); Arco e flecha e a modernização do Japão } \\
\text { (1); Estudo sobre o Laboratório de Pesquisa do Exercício (5); } \\
\text { Escola de Educação Física da UFRGS (1) }\end{array}$ & $\begin{array}{l}\text { História da Educação } \\
\text { Física }\end{array}$ \\
\hline $\begin{array}{l}\text { O que é Educação Física (8); Análise da produção acadêmica } \\
\text { (2); Abordagens teóricas e suas influências nas produções } \\
\text { da Educação Física (4); Dados, interpretações e implicações: } \\
\text { acordos e desacordos (2) }\end{array}$ & $\begin{array}{l}\text { Epistemologia da } \\
\text { Educação Física }\end{array}$ \\
\hline $\begin{array}{l}\text { Lazer, Recreação e estilo de vida (3); Lazer e tempo livre (2); } \\
\text { Lazer de aventura na aventura (6); Explorando o lazer } \\
\text { contemporâneo (4); O discurso do proprietário de academias } \\
\text { sobre prática de natação como atividade de lazer (1); Políticas } \\
\text { Públicas de Lazer (9) }\end{array}$ & Lazer \\
\hline $\begin{array}{l}\text { Treinamento especializado precoce e doping (2); Esporte } \\
\text { desempenho e aptidão física (13); Política de esporte (3); } \\
\text { Elementos Teórico-Metodológicos para o ensino dos esportes } \\
\text { (13); Esporte, uma abordagem social (17); Diferentes } \\
\text { manifestações esportivas (5) }\end{array}$ & Ciência do Esporte \\
\hline $\begin{array}{l}\text { Atividade fisica, saúde e qualidade de vida (22); Composição } \\
\text { corporal (1); Envelhecimento, atividade fisica e treinamento (4); } \\
\text { Postura e lesão (10); Treinamento, avaliação da performance (3); } \\
\text { Atividade fisica abordagem social (7); Avaliação da publicação } \\
\text { da área de saúde (1) }\end{array}$ & Atividade Física e saúde \\
\hline $\begin{array}{l}\text { A educação física e a construção de imagens femininas (7); } \\
\text { Esporte e gênero (14); Homossexualidade e Educação Física (1); } \\
\text { A construção de gênero no espaço escolar (7); }\end{array}$ & Gênero \\
\hline $\begin{array}{l}\text { Corpo, sexualidade e deficiência (1); Educação Física escolar } \\
\text { (5); Educação Física e deficiente visual (1); Política Pública } \\
\text { de inclusão (1); Dança e inclusão (1) }\end{array}$ & $\begin{array}{l}\text { Educação Física } \\
\text { e deficiente }\end{array}$ \\
\hline
\end{tabular}

Quadro 2. Convergência de artigos publicados na revista Movimento

Movimento, Porto Alegre, v. 15, n. 03, p. 57-85, julho/setembro de 2009. 


\section{Antigos Especiais Omar Schneider et al.}

As temáticas privilegiadas na Movimento garantem uma diversidade tanto de objetivo como de perspectiva epistemológica assumida pelos autores que publicam neste periódico, principalmente de 1994 a 2002. Nesse período, encontra-se uma convivência de temas tanto das ciências biológicas e da saúde quanto das ciências humanas e sociais.

Com as reformulações efetuadas a partir de 2002 no projeto editorial, a revista delimita a produção das temáticas tendo como base as Ciências Humanas e Sociais. Ao analisar as temáticas que a Movimento fez circular durante os seus 15 anos de existência, é possível creditar ao periódico uma representatividade do que se produz e discute na área da Educação Física, representatividade essa que poucos impressos brasileiros que tratam dos mesmos assuntos possuem.

\section{A ADEQUAÇÃo CIENTÍFICA DA REVISTA}

No Brasil, um dos instrumentos que veio "popularizar" a avaliação dos periódicos científicos é o Qualis que, apesar de ter sido criado para atender às necessidades específicas de avaliação da pós-graduação brasileira, no que se refere à produção bibliográfica dos programas e não para definir a qualidade de periódicos de forma absoluta, certamente representou um avanço na discussão sobre a qualidade dos periódicos, na medida em que colocou esse tema definitivamente na agenda das universidades. ${ }^{30}$

Os estudos sobre a avaliação dos padrões de qualidade de revistas científicas enfocam, essencialmente, os aspectos intrínsecos e extrínsecos. Assim, a avaliação pode ocorrer de duas formas: avaliação de mérito e de desempenho. A primeira, normalmente realizada por pares, pretende verificar aspectos como qualidade dos artigos (originalidade, atualidade, identificação com a temática da revista e percentual

\footnotetext{
${ }^{30} \mathrm{O}$ novo sistema de avaliação dos periódicos científicos, implementado em 2008, parte de diretrizes comuns a todas as áreas que estão sendo especificadas, tendo em vista os critérios de cada campo. Existem critérios mínimos para que uma revista se enquadre como periódico científico. Uma vez atendidos esses critérios, exigências adicionais servirão para conceituar os periódicos em oito estratos (A1, A2, B1, B2, B3, B4, B5, C).

Movimento, Porto Alegre, v. 15, n. 03, p. 57-85, julho/setembro de 2009.
} 
de artigos originais); qualidade do corpo editorial e dos consultores (participação de membros da comunidade nacional e estrangeira); natureza do órgão publicador, abrangência, indexação, entre outros. A segunda verifica aspectos como normalização, duração, periodicidade, difusão, colaboração de autores e divisão de conteúdo.

Em meio ao processo de modificações em sua proposta gráfica e editorial, a Movimento passou por uma avaliação formal, realizada por Ferreira Neto e Nascimento, em 2002, como parte de um trabalho que buscou avaliar outras dez revistas da Educação Física, a fim de verificar o grau de adequação das revistas às normas formais. ${ }^{31} \mathrm{~A}$ avaliação permitiu indicar alguns pontos que precisavam ser melhorados para garantir um padrão de normalização da revista e, então, contribuir para sua indexação em bases de dados nacionais e internacionais.

Após a análise, alguns procedimentos indicados pelos avaliadores foram incorporados, passando a constituir a "terceira fase" da revista, em que esta assume o design livro, deixando a conotação de "guarda-chuva".

A fim de permitir uma leitura comparativa acerca da adequação científica da revista, procedeu-se, novamente, à sua avaliação formal, utilizando o mesmo instrumento que pode ser visualizado na Fig. 2:

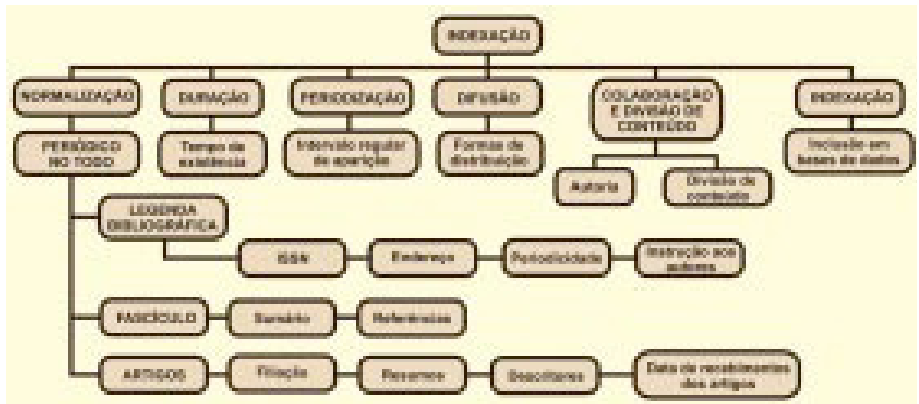

Figura 2. Modelo para a avaliação de periódicos científicos adaptado de Hayashi et al (2006).

\footnotetext{
${ }^{31} \mathrm{O}$ instrumento, adaptado de Kryzanowski e Ferreira (1998), foi publicado no v. 8, n. 2, de 2002. O resultado do trabalho demonstrou que as revistas da área sofriam com a falta de

Movimento, Porto Alegre, v. 15, n. 03, p. 57-85, julho/setembro de 2009.
} 


\section{Antigor Especiais}

Omar Schneider et al.

A avaliação realizada seguiu o mesmo procedimento adotado anteriormente, com aplicação do instrumento aos quatro últimos fascículos publicados. A forma de realizar a avaliação é bastante similar, independentemente da área do conhecimento envolvida. Ela pode ser padronizada e automatizada, de modo a ser aplicada uniformemente a revistas de todas as especialidades e ser executada por técnicos treinados (não precisam ser pesquisadores da área). A avaliação da dimensão técnico-normativa integra os procedimentos de avaliação de agências de fomento e de indexadores.

A pontuação para cada variável e o total geral alcançado permite uma classificação geral de desempenho de cada periódico analisado. Cada variável apresenta uma pontuação correspondente e, para cada conjunto de variável, é atribuído um peso, ficando assim distribuído: Normalização - 25\%; Duração - 5\%; Periodicidade $12 \%$; Indexação - $15 \%$; Difusão - 3\%; e Colaboração de autores e divisão de conteúdos $-40 \%$. Assim, dentro de cada um desses conjuntos, há um número máximo de pontos que pode ser obtido pela revista. Para que se consiga o desempenho do fascículo, deve-se relacionar o total de pontos obtidos pela revista dentro de determinado conjunto com o peso atribuído a ele. O desempenho geral é obtido com a soma das pontuações alcançadas em cada um dos conjuntos, considerando a seguinte classificação: NÍVEL A - acima de $90 \%$ (excelente); NÍVEL B - de 71\% a 90\% (muito bom); NÍVEL C - de $51 \%$ a $70 \%$ (bom); NÍVEL D - de $31 \%$ a $50 \%$ (regular); NÍVEL E - menor ou igual a 30\% (fraco).

Os resultados obtidos com a aplicação do instrumento de avaliação podem ser visualizados no quadro a seguir:

\begin{tabular}{|l|c|c|c|c|}
\hline \multirow{2}{*}{$\begin{array}{c}\text { Critérios de } \\
\text { Avaliação }\end{array}$} & \multicolumn{4}{|c|}{ Fascículos Avaliados } \\
\cline { 2 - 5 } & v. 14, n. 1 & v. 14, n 2 & v. 14, n. 3 & v. 15, n. 1 \\
\hline Legenda bibliográfica & Apresenta & Apresenta & Apresenta & Apresenta \\
\hline ISSN & Apresenta & Apresenta & Apresenta & Apresenta \\
\hline
\end{tabular}

continua...

profissionalismo, desde a produção dos artigos até a distribuição, passando pela editoração. Entre os principais problemas encontrados, destacam-se: falta de normalização dos artigos e das revistas como um todo, descumprimento da periodicidade, distribuição deficiente, abrangência local ou regional, baixo índice de artigos originais e falta de uma política editorial.

Movimento, Porto Alegre, v. 15, n. 03, p. 57-85, julho/setembro de 2009. 
...continuação

\begin{tabular}{|c|c|c|c|c|}
\hline Endereço & Completo & Completo & Completo & Completo \\
\hline Periodicidade & Apresenta & Apresenta & Apresenta & Apresenta \\
\hline $\begin{array}{l}\text { Instruções } \\
\text { aos autores }\end{array}$ & Completa & Completa & Completa & Completa \\
\hline Sumário & Português, Inglês & Português, Inglês & Português, Inglês & Português, Inglês \\
\hline Referências & Normalizadas & Normalizadas & Normalizadas & Normalizadas \\
\hline Filiação dos autores & Completa & Completa & Completa & Completa \\
\hline Resumos & $\begin{array}{l}\text { Português, Inglês } \\
\text { Espanhol }\end{array}$ & $\begin{array}{l}\text { Português, Inglês } \\
\text { Espanhol }\end{array}$ & $\begin{array}{l}\text { Português, Inglês } \\
\text { Espanhol }\end{array}$ & $\begin{array}{c}\text { Português, Inglês; } \\
\text { Espanhol }\end{array}$ \\
\hline Descritores & Apresenta & Apresenta & Apresenta & Apresenta \\
\hline $\begin{array}{l}\text { Data de recebimento } \\
\text { dos artigos }\end{array}$ & Apresenta & Apresenta & Apresenta & Apresenta \\
\hline Duração & 14 anos & 14 anos & 14 anos & 14 anos \\
\hline Periodicidade & Quadrimestral & Quadrimestral & Quadrimestral & Trimestral \\
\hline Difusão & Venda/assinatura & Venda/assinatura & Venda/assinatura & Venda/assinatura \\
\hline Autoria & Não apresenta & $\begin{array}{c}\text { Mínimo de } 10 \% \\
\text { de autores } \\
\text { estrangeiros } \\
\text { ou colaboração }\end{array}$ & Não apresenta & $\begin{array}{c}\text { Mínimo de } 10 \% \\
\text { de autores } \\
\text { estrangeiros } \\
\text { ou colaboração }\end{array}$ \\
\hline Artigos originais & $\begin{array}{c}50 \% \text { de artigos } \\
\text { originais }\end{array}$ & $\begin{array}{c}50 \% \text { de artigos } \\
\text { originais }\end{array}$ & $\begin{array}{c}50 \% \text { de artigos } \\
\text { originais }\end{array}$ & $\begin{array}{c}50 \% \text { de artigos } \\
\text { originais }\end{array}$ \\
\hline Artigos de revisão & Apresenta & Apresenta & Apresenta & Apresenta \\
\hline Cartas & Não apresenta & Não apresenta & Não apresenta & Não apresenta \\
\hline Resenhas & Apresenta & Apresenta & Apresenta & Apresenta \\
\hline Estudo de caso & Não apresenta & Não apresenta & Não apresenta & Não apresenta \\
\hline Indexação & $\begin{array}{l}\text { SportDiscus; } \\
\text { Lilacs Laptoc; } \\
\text { Latindex; }\end{array}$ & $\begin{array}{c}\text { Sport Discus; } \\
\text { Laptoc; Latindex; } \\
\text { Lilacs }\end{array}$ & Sport Discus ${ }^{32}$ & $\begin{array}{l}\text { Sport Discus; } \\
\text { Lilacs; Latindex }\end{array}$ \\
\hline
\end{tabular}

Quadro 3. Resultado da avaliação da revista Movimento

O resultado demonstra que o melhor desempenho foi obtido pelo último fascículo, classificado como B, em função da inclusão de artigos de autores estrangeiros ou em colaboração com esses e também pela modificação da proposta de periodicidade, que passou a ser trimestral. Os demais fascículos foram classificados como nível D. ${ }^{33}$

${ }^{32}$ A informação relacionada com a indexação nas outras bases de dados não pode ser localizada na versão impressa desse fascículo, o que faz com que a revista deixe de pontuar nesse conjunto.

${ }^{33} \mathrm{~A}$ avaliação pelo Qualis utiliza como referência os indexadores que classificam as revistas em estratos de A a C. Ferreira Neto e Nascimento (2002) apresentam um instrumento de avaliação para a área da Educação Física, que envolve outras variáveis de amplo reconhecimento na bibliografia sobre práticas editoriais de periódicos científicos. Desse modo, a classificação tende a ser diferente daquela praticada pela Capes.

Movimento, Porto Alegre, v. 15, n. 03, p. 57-85, julho/setembro de 2009. 
De maneira geral, os resultados revelam características importantes da revista e, embora algumas delas já tenham sido atingidas com excelência, como pode ser identificado no Quadro 3, outras ainda podem ser aprimoradas. De fato, como apontam Gonçalves, Ramos e Castro (2006), a qualidade de uma revista não é valor facilmente mensurável ou completamente tangível, pois sua estrutura é formada por um conjunto de diversos aspectos como: conteúdo, forma de apresentação, normalização e produção editorial. Assim, ainda que a qualidade do conteúdo seja fator determinante para a qualidade de uma revista, os aspectos formais das publicações constituem importantes indicadores, tendo em vista que permitem a sua localização e disseminação.

\section{A INVISIBILIDADE DA FORMA CIENTIFICA}

No campo da produção editorial de revistas científicas, a normalização é um dos quesitos que determinam em grande parte seu projeto gráfico e atua, segundo Gruszynski (2006), como uma atividade reguladora que busca facilitar a transferência de informações ao unificar formas e procedimentos.

Ainda que a qualidade de um periódico científico dependa fundamentalmente da qualidade de seus conteúdos, sua significação passa pela materialidade dos suportes. A qualificação das características formais da publicação, deste modo, contribui para a consolidação e credibilidade de uma revista (GRUSZYNSKI, 2006, p. 11).

Tornam-se essenciais, nesse contexto, informações sobre a periodicidade adotada, instruções aos autores, endereço e a presença de legenda bibliográfica ${ }^{34} \mathrm{em}$ todas e em cada uma das páginas do texto. Nesse sentido, a Movimento precisa atentar para a necessidade de

\footnotetext{
34 Depois da publicação do número 15 , no ano de 2001 , quando o periódico passa a ser quadrimestral, toma-se a decisão de modificar a forma como a revista organiza o registro de sua legenda bibliográfica. Ela deixa de ser apresentada fazendo referência ao ano de publicação e a uma numeração progressiva. No novo projeto, o ano se torna volume e a numeração passa a ser representativa da quantidade de publicações produzidas durante um ano, com a referência a quais meses o impresso é produzido dentro da quadrimestralidade.

Movimento, Porto Alegre, v. 15, n. 03, p. 57-85, julho/setembro de 2009.
} 
inclusão da legenda em todas as páginas, tendo em vista que essa permite a rápida identificação da publicação.

Dentre os diferentes critérios analisados, fica evidente a necessidade de incentivar a circulação de autores estrangeiros, bem como a sua colaboração. A capacidade da revista em atrair colaboradores está diretamente relacionada com seu prestígio na comunidade científica e sua disseminação, ou seja, prestígio e público andam juntos. Os leitores, como os autores, são atraídos pelos periódicos mais importantes, de modo que, ao publicar nesses periódicos, os autores possuem maiores condições de criar uma maior comunidade de leitores (MEADOWS, 1999).

Ao analisar a circulação dos autores na Movimento, percebe-se o predomínio das Regiões Sul e Sudeste, o que pode ser caracterizado como uma "endogenia geográfica" ${ }^{35}$. No entanto, é necessário considerar que essas regiões concentram a maioria dos programas de pósgraduação que são reconhecidos como os polos de produção científica e que a produção veiculada pela revista representa "[...] aquilo que os pesquisadores em Educação Física fazem" (MOLINA NETO; STIGGER, 2008, p. 8), demonstrando que a endogenia geográfica também representa um momento, dado que este é um problema que indica o estágio de desenvolvimento da área.

Além desses aspectos, a circulação apresenta-se como elemento estratégico para a consolidação de um periódico, sendo decisiva a sua regularidade, distribuição ${ }^{36}$ e difusão. Para que se mantenha constante e atinja o público-alvo, é preciso prever uma periodicidade possível de ser mantida ao longo do tempo, garantindo continuidade à coleção.

Pensar a difusão de uma publicação impressa consiste em assegurar sua presença em bases de dados. Difusão e Indexação são

\footnotetext{
${ }^{35}$ A expressão endogenia, no processo de avaliação de periódicos, pode ser utilizada em relação a concentração institucional e geográfica do conselho editorial e/ou dos autores. Essa avaliação é realizada com base na afiliação declarada do conselho editorial, dos revisores e dos autores. A apuração de tendência à concentração institucional ou geográfica desses elementos é considerada como um resultado negativo para a admissão do periódico em bases de dados.

${ }^{36}$ A distribuição indica a tiragem de cada número. É indispensável informar suas possíveis formas de aquisição - assinatura, permuta, distribuição gratuita, compra avulsa -, bem como se está disponível em outro formato - on-line.
}

Movimento, Porto Alegre, v. 15, n. 03, p. 57-85, julho/setembro de 2009 
critérios que estão intimamente ligados e dizem sobre a eficiência da revista no processo de distribuição e divulgação que, por conseguinte, atestam sobre sua visibilidade. Sem dúvida, a disseminação concretiza-se pela indexação. Segundo Packer e Meneghini (2006, p. 251), "[...] quanto mais ampla é [a] distribuição, maior é o potencial de visibilidade do periódico". Assim, é possível inferir que a visibilidade dos periódicos depende da eficiência de sua distribuição e divulgação, bem como de sua indexação.

Quanto maior a visibilidade de um periódico, maior é seu potencial de fazer com que seus artigos sejam acessados, lidos e citados. Nesse sentido, ao ser indexada em bases de dados internacionais, a revista caminha para se tornar uma referência na área, tendo em vista que estar indexada e ser reconhecida são dimensões que estão relacionadas, de forma que "[...] a condição ou potencial de referência de qualidade e credibilidade parece ser a força dominante na construção e consolidação da visibilidade dos periódicos" (PACKER; MENEGHINI, 2006, p. 239).

Se qualidade e credibilidade são características intrínsecas a uma publicação de referência, sua visibilidade depende, também, da capacidade de ser localizada. Nesse sentido, a entrada da revista no Sistema Eletrônico de Editoração de Revistas (SEER) ${ }^{37}$ mostrou-se relevante, uma vez que ampliou a visibilidade da publicação. Nesse formato eletrônico, a revista encontra-se disponível on-line, com seus textos apresentados em português, e os resumos das edições, assim como as instruções para os leitores e autores, em inglês e espanhol. ${ }^{38}$

No item Divisão de conteúdo, é recomendado que sejam priorizados os artigos originais, destinando, no mínimo, $70 \%$ de seu espaço para essas produções. Nota-se que a revista não tem conseguido manter

\footnotetext{
${ }^{37}$ No Brasil, o Instituto Brasileiro de Informação e Tecnologia (IBICT) traduziu e adaptou o software Open Journal System (OJS), livre e de fonte aberta, dando origem ao Sistema Eletrônico de Editoração de Revistas (SEER). Por meio dele, os editores científicos podem gerenciar seus periódicos de acordo com as próprias políticas editoriais, desde a submissão dos artigos até a publicação on-line e a indexação. Ao operacionalizar o fluxo editorial, otimiza a eficácia do processo. O SEER pode ser usado também na produção de revistas impressas, abrangendo até a fase de revisão de textos a serem diagramados.

${ }^{38}$ A home page da revista pode ser acessada no site http://www.seer.ufrgs.br/index.php/Movimento.

Movimento, Porto Alegre, v. 15, n. 03, p. 57-85, julho/setembro de 2009.
} 
essa média, incluindo artigos de revisão (ensaios) que, apesar de serem considerados, agregam menor valor à publicação.

O entendimento dos dois gêneros (artigos originais e ensaios) é diversificado e polêmico e a revista tem buscado encontrar uma definição que atenda aos objetivos de sua política editorial, bem como da própria área. Até a publicação do ano 7, número 15 (2001), o entendimento de artigo original estava relacionado à não publicação da contribuição em outra revista. No volume 8 , número 1 (2002), a revista realiza alterações nas instruções aos autores, destacando que os artigos originais incluem contribuições que apresentam " [...] temas e abordagens próprias, destinando-se exclusivamente a publicação na Movimento [...] [e os ensaios são entendidos como] reflexões e discussões acerca dos temas da área" (MOVIMENTO, 2002, p. 67).

A partir do volume 9, número 2 (2003), a revista deixa de apresentar uma diferenciação entre os dois gêneros e passa a informar que adotará as seções Em Foco, Espaço Aberto e Resenha. No entanto, a análise do sumário permite notar que a revista mantém a classificação dentro das seções. Ainda que tenham deixado de ser publicadas no volume 13, número 1 (2007), as instruções mantiveram a mesma divisão. $\mathrm{O}$ número 2 , publicado no mesmo ano, já indica uma nova classificação, diferenciando artigos originais, ensaios e resenha.

Para Gruszynski e Sanseverino (2005), como conhecimento e interesse estão próximos, é complexo avaliar o caráter científico de um periódico em humanidades, segundo o critério da originalidade ou da novidade de uma hipótese ou de um resultado, pois a tendência é torná-lo discutível e dificilmente consensual. Nesse caso, os autores sugerem considerar a referência bibliográfica utilizada, as citações feitas e a contribuição que o texto publicado traz para a bibliografia da área em questão.

Além disso, os mesmos autores (2005) apontam que cada área apresenta uma forma de linguagem e a definição do que considera aceitável cientificamente, estabelecendo modelos de interpretação e de fixação de sentido. Desse modo, interessa haver critérios para a constituição de revistas que possam garantir a circulação do conhecimento, servindo como meio de legitimar academicamente os artigos publicados.

Movimento, Porto Alegre, v. 15, n. 03, p. 57-85, julho/setembro de 2009. 


\section{Antigor Especiais}

Omar Schneider et al.

A qualidade científica de uma publicação está intimamente relacionada com a originalidade, atualidade e identificação dos artigos, com a orientação temática, com a linha da revista e com sua identidade. De fato, poucas revistas na Educação Física têm conseguido definir uma linha editorial e se estabelecer dentro da comunidade científica. Esse fato decorre das dificuldades encontradas para obter artigos de qualidade consoantes a proposta editorial, ficando a revista, então, à mercê de artigos de balcão, ou seja, da colaboração espontânea dos pesquisadores. A definição da missão da revista é, então, fundamental para a obtenção de submissões de qualidade, tornando-a forte e atraente o suficiente também para a captação de recursos orçamentários. Além disso, entende-se que ela permitirá sua indexação nas diferentes bases de dados.

É preciso compreender que todas as mudanças realizadas no projeto editorial e gráfico da Movimento, buscaram garantir à revista uma representatividade e legitimidade na área como veículo autorizado de disseminação do conhecimento produzido pela comunidade acadêmica.

Nem sempre se torna possível ao editor "bancar" formatos, propostas, temáticas, em função do risco de estar fora do circuito das revistas indexadas. Torna-se necessário, então, pensar em possibilidades/táticas capazes de manter a revista entre as que circulam e interessam à comunidade científica e conseguir, ao mesmo tempo, manter sua identidade.

Movimento, Porto Alegre, v. 15, n. 03, p. 57-85, julho/setembro de 2009. 
Archeology of editiorial practices: 15 years of a printed press in movement

Abstract: The paper studies the archeology of editorial practices of the journal Movimento regarding the processes of editing, diffusion, circulation and adaptation to the index agencies. It reveals the phases of the printed material emphasizing the choices of the editors with reference to the graphical project of the periodic that puts in circulation different devices of regulation of the appropriations, at the same time when it aims at creating an identity that qualifies the periodic as an authorized gadget able to show the readers what Physical Education is in Brazil.

Keywords: Movimento Journal. Evaluation. Scientific and technical publications.

Arqueología de práticas editoriales: 15 años de un impreso en movimiento

Resumen: Estudia la arqueología de prácticas editoriales de la revista Movimento en relación con los procesos de edición, difusión, circulación y adecuación a agencias indexadoras. Revela las fases del impreso enfatizadas a escojas de editores con referencia al proyecto gráfico del periódico que hace circular diferentes aparatos de regulación de apropiaciones, al mismo tiempo en que busca crear una identidad que cualifique el periódico como dispositivo autorizado, capaz de revelar a los lectores lo que es la Educación Física en Brasil.

Palabras Clave: Revista Movimento. Avaliación Publicaciones científicas y técnicas.

\section{REFERÊNCIAS}

ANDRADE FILHO, N. F. de. Formação profissional em educação física brasileira: uma súmula da discussão dos anos de 1996 a 2000. Revista Brasileira de Ciências do Esporte, Campinas, v. 22, n. 3, p. 23-38, maio 2001.

ANDRADE FILHO, N. F. de; FIGUEIREDO, Z.C.C. Formação profissional em educação física brasileira: súmula da discussão dos anos 2001 a 2004. In: CAPARRÓZ, F. E.; ANDRADE FILHO, N. F. de (Org.). Educação física escolar: políticas, investigação e intervenção. Vitória: Ufes, Lesef: Uberlândia:UFU, NEPECC, 2004. p. 129-154.

ANTUNES, A. As coisas. São Paulo: lluminuras, 1993.

ASSIS, M. de. Quincas borba. São Paulo: Ática, 1973.

Movimento, Porto Alegre, v. 15, n. 03, p. 57-85, julho/setembro de 2009. 
BARRADAS, M.M.; TARGINO, M. das G. Redação de artigos técnico-científicos: a pesquisa transformada em texto. In: FERREIRA, S.M.S.P.; TARGINO, M. das G. (Org.). Mais sobre revistas científicas: em foco a gestão. São Paulo: Senac São Paulo/ Cengage Learnig, 2008, p. 17-39.

BIOJONE, M.R. Os periódicos científicos na comunicação da ciência. São Paulo: Educ/Fapesp, 2003.

BRACHT, V. Esporte na escola e esporte de rendimento. Movimento, Porto Alegre, v. 6, n. 12, p. XIV-XXIV, jul. 2000.

BRACHT, V. Mas, afinal, o que estamos perguntando, com a pergunta "o que é educação física?" Movimento, Porto Alegre, ano II, n. 2, p. I-VIII, jun. 1995.

CASTEDO, R. da S. O projeto gráfico de periódicos científicos: um estudo sobre o projeto gráfico da Revista da Faculdade de Biblioteconomia e Comunicação FABICO/UFRGS. In: Congresso Brasileiro de Ciências da Comunicação, 29., 2006, Brasília. Anais... Brasília: Intercom, 2006.

CASTEDO, R. da S.; GRUSZYNSKI, A.C. O projeto gráfico de periódicos científicos: uma contribuição aos roteiros de avaliação. Em Questão, Porto Alegre, v. 11, n. 2, p. 313-333, jul./dez. 2005.

CERTEAU, M. de. A invenção do cotidiano: as artes de fazer. Petrópolis: Vozes, 1994.

CHARTIER, R. À beira da falésia: a história entre certezas e inquietude. Porto Alegre: Editora da Universidade Federal do Rio Grande do Sul, 2002.

CHARTIER, R. A história cultural: entre práticas e representações. Lisboa: Difel, 1990.

CHARTIER, R. A ordem dos livros: leitores, autores e bibliotecas na Europa entre os séculos XIV e XVIII. Brasília: Editora da Universidade de Brasília, 1994.

COSTA, L.P. da. Uma questão ainda sem resposta: o que é a educação física? Movimento, Porto Alegre, ano III, n. 4, p. I-X, 1996.

FERREIRA NETO, A.; NASCIMENTO, A.C.S. Periódicos científicos da Educação Física: posposta de avaliação. Movimento, Porto Alegre, v. 8, n. 2, p. 35-49, maio/ ago, 2002.

FERREIRA, S.M.S. et al. Critérios de qualidade para as revistas científicas em comunicação. In: FERREIRA, S.M.S.; TARGINO, M. das G.(Org.). Preparação de revistas científicas: teoria e prática. São Paulo: Reichmann e Autores, 2005. p. $269-293$.

GAYA, A. et al. Crescimento e desempenho motor em escolares de 7 a 15 anos provenientes de famílias de baixa renda: indicadores para o planejamento de programas de educação física voltados à promoção de saúde. Movimento, Porto Alegre, v. 3, n. 6, p. I-XXIV, 1997.

Movimento, Porto Alegre, v. 15, n. 03, p. 57-85, julho/setembro de 2009. 
GAYA, A. Mas, afinal, o que é educação física. Movimento, Porto Alegre, v. 1, n. 1, [s. p.], set. 1994.

GAYA, A. Sobre o esporte para crianças e jovens. Movimento, Porto Alegre, v. 7, n. 13, p. I-XIV, dez. 2000.

GAYA, A.; TORRES, L.; CARDOSO, M. Dados, interpretações e implicações: acordos e desacordos ( $1^{a}$ parte: a metodologia em questão). Movimento, Porto Alegre, ano IV, n. 8, p. I-XX, 1998.

GAYA, A.; TORRES, L.; CARDOSO, M. Dados, interpretações e implicações: acordos e desacordos (2a parte: as questões conceituais). Movimento, Porto Alegre, ano V, n. 9, p. I-XII, 1998.

GHIRALDELLI, P. A volta ao que parece simples. Movimento, Porto Alegre, ano II, n. 2, p. XV-XVII, jun. 1995.

GONÇALVES, A.; RAMOS, L.M.; CASTRO, R.F. Revistas científicas: características, funções e critérios de qualidade. In: POBLACIÓN, D.A.; WITTER, G.P.; SILVA, J.F.M. (Org.). Comunicação \& Produção científica: contexto, indicadores e avaliação. São Paulo: Angellara, 2006. p. 163-190.

GRUSZYNSKI, A.C. Design gráfico: do invisível ao ilegível. São Paulo: Edições Rosari, 2008.

GRUSZYNSKI, A.C.; GOLIN, C.; CASTEDO, R. da S. Produção editorial e comunicação científica: uma proposta para edição de periódicos científicos. In: Congresso Brasileiro de Ciências da Comunicação, 31., 2008, Natal. Anais... Natal: Intercom, 2008.

GRUSZYNSKI, A.C. O design de periódicos científicos no Brasil: projeto de leitura e campo científico. In: Congresso Brasileiro de Pesquisa e Desenvolvimento em Design, 7., 2006, Curitiba. Anais... Curitiba: P\&D, 2006.

GRUSZYNSKI, A.C.; SANSEVERINO, A.M.V. O periódico científico na área de Humanidades: critérios de avaliação. In: Congresso Brasileiro de Ciências da Comunicação, 28., 2005, Rio de Janeiro. Anais... Rio de Janeiro: Intercom, 2005.

HAYASHI, M.C.P.I.; HAYASHI, C.R.M.; LIMA, M.Y. de; SILVA, M.R. da; GARRUTTI, É.A. Avaliação de aspectos formais em quatro periódicos científicos na área de Educação Especial. Revista Brasileira Educação Especial, Marília, v. 12, n. 3, p. 369-392, set./dez. 2006.

KRZYZANOWSKI, R.F.; FERREIRA, M.C.G. Avaliação de periódicos científicos e técnicos brasileiros. Ciência da informação, Brasília, v. 27, n. 2, p. 165-175, maio/ago. 1998.

KUNZ, E. Esporte: uma abordagem com a fenomenologia. Movimento, Porto Alegre, v.6, n. 12, p. I-XIII, jul. 2000.

LIMA, L.C. (Org.). A literatura e o leitor: textos de estética da recepção. Rio de Janeiro: Paz e Terra, 1979.

Movimento, Porto Alegre, v. 15, n. 03, p. 57-85, julho/setembro de 2009. 


\section{Artigor Especiais}

Omar Schneider et al.

LOVISOLO, H. Dados, interpretações e implicações. Movimento, Porto Alegre, v. 4, n. 7, p. I-VIII, 1997.

LOVISOLO, H. Mas, afinal, o que é Educação Física? A favor da mediação e contra os radicalismos. Movimento, Porto Alegre, v.2, n. 2, p. XVIII-XXIV, jun. 1995.

LOVISOLO, H. Mediação: esporte rendimento e esporte da escola. Movimento, Porto Alegre, v.7, n. 15, p. 105-117, dez. 2001

MEADOWS, A.J. A Comunicação Científica. Tradução de Antonio Agenor Briquet de Lemos. Brasília: Briquet de Lemos, 1999.

MOLINA NETO, V. Editorial. Movimento, Porto Alegre, v.5, n. 11, p. 2, 1999.

MOLINA NETO, V. Editorial. Movimento, Porto Alegre, v. 6, n. 12, p. 4, jul. 2000.

MOLINA NETO, V. Editorial. Movimento, Porto Alegre, v.7, n. 14, p. 7, jul. 2001.

MOLINA NETO, V. Editorial. Movimento, Porto Alegre, v. 8, n. 1, p. 7, jan./abr. 2002.

MOLINA NETO, V. Editorial. Movimento, Porto Alegre, v. 8, n. 2, p. 2, maio/ago. 2002.

MOLINA NETO, V.; GOELLNER, S.V.; STIGGER, M.P. Editorial. Movimento, Porto Alegre, v. 8, n. 3, p. 4, set./dez. 2002.

MOLINA NETO, V.; MOLINA, R.K. Capacidade de escuta: questões para a formação docente em educação física. Movimento, Porto Alegre, v. 8, n. 1, p. 57-66, jan./ abr. 2002

MOLINA NETO, V.; STIGGER, M.P. Editorial. Movimento, Porto Alegre, v. 12, n. 3, p. 7-9, set./dez. 2006.

MOLINANETO, V.; STIGGER, M.P. Editorial. Movimento, Porto Alegre, v. 14, n. 2, p. 7-9, maio/ago. 2008.

MOVIMENTO. Normas para publicação, Porto Alegre, v. 8, n. 1, p. 67, 2002.

NOSELLA, P. Compromisso político como horizonte da competência técnica. Educação \& Sociedade, São Paulo, v. 5, n. 14, p. 91-97, maio 1983.

OLIVEIRA, D.R. de; SCHINCARIOL, Z. A tipografia da revista gráfica: mutabilidade e identidade. In: Congresso Internacional de Pesquisa em Design, 4., 2007, Rio de Janeiro. Anais... Rio de Janeiro: Anped, 2007.

PACKER, A.L.; MENEGHINI, R. Visibilidade da produção científica. In: POBLACIÓN, D.A.; WITTER, G.P.; SILVA, J.F.M. (Org.). Comunicação \& Produção científica: contexto, indicadores e avaliação. São Paulo: Angellara, p. 235-259, 2006.

PALAFOX, G.H.M. O que é educação física? Uma abordagem curricular. Movimento, Porto Alegre, v.3, n. 4, p. XI-XIV, 1996.

Movimento, Porto Alegre, v. 15, n. 03, p. 57-85, julho/setembro de 2009. 
SANTIN, S. A respeito de comentários. Movimento, Porto Alegre, v.2, n. 2, p. IXXIV, jun. 1995

SAVIANI, D. Competência política e compromisso técnico ou (o pomo da discórdia e o fruto proibido). Educação \& Sociedade, São Paulo, v.5, n. 15, p. 111-143, ago. 1983.

SOUZA, J.L. de. Editorial. Movimento, Porto Alegre, v. 5, n. 10, p. 2, 1999.

STIGGER, M.P. Editorial. Movimento, Porto Alegre, v. 1, n. 1, p. 4-5, set. 1994.

STIGGER, M.P. Editorial. Movimento, Porto Alegre, v. 2, n. 2, p. 4-5, set. 1995.

STIGGER, M.P. Passado e futuro das revistas científicas. Ciência da Informação, Brasília, v. 25, n. 3, p. 383-386, set./dez. 1996

STIGGER, M.P. Relações entre o esporte de rendimento e o esporte da escola. Movimento, Porto Alegre, v. 7, n. 14, p. 67-86, jul. 2001.

STUMPF, I.R.C. Reflexões sobre as Revistas Brasileiras. Intexto, Porto Alegre, v. 1, n. 3, p. 1-10, jan./jun. 1998.

TAFFAREL, C.N.Z; ESCOBAR, M.O. Mas, afinal, o que é educação física?: um exemplo do simplismo intelectual. Movimento, Porto Alegre, ano I, n. 1, [s. p.], set. 1994.

TAFFAREL, C.N.Z. Desporto educacional: realidade e possibilidades das políticas governamentais e das práticas pedagógicas nas escolas públicas. Movimento, Porto Alegre, ano VII, n. 13, p. XV-XXXV, dez. 2000.

TARGINO, M. das G. Comunicação científica: uma revisão de seus elementos básicos. Informação \& Sociedade: Estudos, João Pessoa, v. 10, n. 2, p. 37-85, 2000.

VAZ, A.F. Técnica, esporte, rendimento. Movimento, Porto Alegre, ano VII, n. 14, p. 87-99, jul. 2001.

VIEIRA, A.; SOUZA, J.L. de. Verticalidade é sinônimo de boa postura? Movimento Porto Alegre, v. 5, n. 10, p. I-VIII, 1999.

WATERS, L Inimigos da esperança: publicar, perecer e o eclipse da erudição. São Paulo: Editora da Unesp, 2006.

YAMAMOTO, O.H. et al. Avaliação de periódicos científicos brasileiros da área da Psicologia. Ciência da Informação, Brasília, v. 31, n. 2, maio/ago. 2002.

YAMAMOTO, O.H. et al. Periódicos científicos em psicologia: uma proposta de avaliação. Infocapes, Brasília, v. 7, n. 3, p. 7-13, jul./set. 1999.

Movimento, Porto Alegre, v. 15, n. 03, p. 57-85, julho/setembro de 2009. 